\title{
Violência na mídia ou violência na sociedade? A leitura da violência na mídia
}

\section{RESUMO}

Este artigo discute a questão da violência e sua representação na televisão, apresentando os resultados de uma ampla pesquisa de recepção, com emprego das abordagens qualitativa e quantitativa, na busca pela atribuição de sentido pela recepção. $\mathrm{O}$ resultado da análise dos discursos dos emissores e receptores mostra-nos o cenário de uma sociedade mediática, dependente da televisão como fonte de informação; porém uma informação que é elaborada conforme o entorno social e cultural. Para o receptor, o consumo é imediato, não há espaço para reflexão. As notícias devem ser breves e objetivas. Os programas jornalísticos apenas retratam os acontecimentos da cidade, não sendo violentos em si. A violência fica mais caracterizada nos programas relacionados ao entretenimento, na medida em que desrespeitam o ser humano.

\section{PALAVRAS-CHAVE}

- televisão

- recepção

- violência

\section{ABSTRACT}

This article discusses violence and its representation on television, showing the results of a comprehensive reception research, employing qualitative and quantitative approaches. The results show us a society centered in the media, that depends on television for information, although such information is elaborated according to social and cultural environments. Consumption has to be quick, there is no time for reflection. News has to be short and objective. News programs only show city facts, not being violent themselves. Violence is best characterized on programs related to entertainment, as they do not respect the human being.

\section{KEY WORDS}

- television

- reception

- violence

\section{Marcia Perencin Tondato UMESP}

A trajetória do homem ao longo dos últimos séculos, em especial do século XX, criou um ambiente propício para que se considerasse a Violência como algo inerente à natureza humana. Mas é na contemporaneidade que a questão da violência torna-se motivo de preocupação, como se todas as transformações ocorridas da Antiguidade à Idade Moderna tivessem acontecido de forma pacífica, consensual, sem injustiças, mortes e destruição. É como se a violência fosse invenção do homem moderno ao promover a exploração, o escravismo, o colonialismo, a dependência cultural e econômica.

Em fala sobre Comunicação e Cultura pela Paz, durante o X Encontro Latino-Americano das Faculdades de Comunicação Social, ${ }^{1}$ o prof. Octávio Ianni definiu Violência como um "evento heurístico, um momento enlouquecido em que a sociedade se revela". Hoje, quando pensamos em violência, o que certamente nos vem à mente é o ambiente dos grandes centros urbanos, caracterizados pela heterogeneidade, densidade e grandeza, elementos geradores das suas características sociológicas, que a todos influenciam pelo anonimato, mobilidade, segregação, instabilidade e insegurança. ${ }^{2}$

No aspecto macro, tais transformações refletem e refratam a dinâmica da economia. $\mathrm{O}$ mundo sofre com o terrorismo, que deixa de ser um problema de governos locais e passa a influenciar a vida de todos, seja pela destruição física de vidas e bens, limitação da liberdade de deslocamento, seja pelas repercussões no desenvolvimento dos países. Da mesma forma que na era das grandes navegações, malfeitores, ladrões viajavam junto com colonizadores e desbravadores, hoje, os avanços tecnológicos, as possibilidades de comunicação, colaboram para a disseminação dos atos violentos. No aspecto micro, a vida cotidiana das comunidades sofre influências, não só nos aspectos 'legais', mas também na realidade paralela do crime e da contravenção, com modificações do perfil do bandido, como retratado em romances ${ }^{3}$ e, mais recentemente, em matérias jornalísticas. $^{4}$

No Brasil, em 20 anos, a população urbana subiu da casa dos $50 \%$ para $80 \%$, sem que isso tenha sido acompanhado pelo desenvolvimento das condições de vida, pelo contrário, cresce a desigualdade, diminuem as chances de ascensão social, aumentando a busca por alternativas ilegais de inserção em uma sociedade marcada pela fragmentação. Até os anos 80 , o crime organizado se restringia à ação de quadrilhas e ao jogo do bicho que, embora considerado contravenção, tem todas as características de organização na medida em que atua em um território 
definido, faz lavagem de dinheiro e tem forte penetração na máquina do Estado. ${ }^{5}$

\section{"a violência é representada por meio de simplificações das complexidades de uma sociedade individualista"}

Na medida em que entra em cenário o tráfico de drogas, é necessário o estabelecimento de novas estratégias, exigindo mudanças estruturais na atuação dos grupos, visto o surgimento de novas oportunidades de negócios ilegais, que necessitam de uma logística diferente que engloba a distribuição e o emprego de mão-de-obra. ${ }^{6}$ Isso acarreta uma violência que aterroriza tendo em vista o emprego mais efetivo da força para eliminar os obstáculos ao crescimento. Em se tratando de uma atuação ilegal, o controle por meio da persuasão ideológica em um contexto de aceitação de situações violentas estabelecidas pela hegemonia, torna-se inviável, ocorrendo apenas em níveis de relacionamentos muito próximos, como no caso em que as facções criminosas utilizam o assistencialismo à comunidade como forma de manutenção da ordem e do poder, ou, ainda, sob o argumento da luta pelos direitos dos presos.

Estudos das manifestações de violência nas festas populares em pequenos lugarejos e nos grandes centros urbanos nos dão uma visão mais sistematizada da evolução do fenômeno. Nos pequenos lugarejos, a violência é mais pensada como algo que vem de fora. O que acontece nas festas são discórdias, ações intempestivas que degeneram em briga, agressão física, muitas vezes causadas por 'estranhos'. Caminhando para a cidade grande, paramos no universo das vizinhanças, onde a ocorrência da situação violenta, na maioria das vezes, é relacionada a grupos definidos, como "uma linguagem que faz parte da lógica contrastiva da construção de identidade". ${ }^{7}$

Daí 'evoluímos' para a violência urbana, o formato mais explorado pelos meios de comunicação, que procuram racionalizar situações, enquadrando acontecimentos nos modelos hegemônicos, estereotipados, resultando, na maioria dos casos, na banalização, como apontado por Michaud ao comentar que "no processo de racionalização da violência (violência admitida, ajeitada, tolerada, enquadrada) (...) as coisas se normalizam e se banalizam. Habituamonos a tudo: até à tortura, cuja volta ao primeiro plano dos instrumentos governamentais suscitou escândalo, hoje não indigna mais" ${ }^{8}$ É no contexto socioeconômico-cultural das metrópoles que se somam as condições necessárias para a realização do ato violento como produto individual e principalmente social, pois é aí que se fazem presentes
(...) tramas e fios que unem o mundo da contravenção ao circuito do crime organizado, no narcotráfico, no contrabando de armas e nos seqüestros, emaranhando-os inextricavelmente às formas de sociabilidade e cultura do mundo popular. (...) representando um atentado à possibilidade mesma de continuidade da vida social. ${ }^{9}$

A partir dessas considerações, trabalhamos com "momentos" de violência mais presentes no cotidiano e/ou no imaginário das pessoas: a guerra e a violência urbana. Como decorrência, temos três manifestações:

1. O ato violento individual, concretizado em estupros, assassinatos em série, que seriam produtos de patologias e cuja exploração pela mídia faz parte de um processo catártico;

2. O ato violento social, exemplificado por seqüestros e latrocínios, produto da busca pela igualdade, seja por aqueles que se sentem injustiçados em uma sociedade de consumo, seja pelo crime que se organiza paralelamente ao poder constituído;

3. O ato violento institucionalizado, do qual as guerras são o produto mais acabado, produto da busca pelo poder político-econômico.

Em uma cultura midiatizada, estas manifestações tornam-se parte do cotidiano através da audiência aos conteúdos jornalísticos, que oferecem 'em um mesmo pacote' os 'fatos' dramatizados da cidade grande, 'ao vivo e em cores', juntamente com 'os últimos lançamentos da moda', interrompidos pelo comercial do carro do ano, a um receptor que busca o equilíbrio, a segurança.

O estudo aqui apresentado em síntese buscou verificar a recepção feita dos programas com conteúdos caracterizados por 'tipos' ou 'formas' de violência, com a exploração das leituras da recepção por meio de entrevistas individuais, grupos focais e análise do conteúdo discursivo da programação. Para responder ao questionamento sobre a leitura feita de uma programação polêmica, criticada pela baixa qualidade, mas que apresenta índices representativos de audiência, as hipóteses geradas na fase exploratória foram em uma avaliação quantitativa dos hábitos de consumo dos meios de uma amostra de 450 casos distribuídos por classes socio-econômicas, gênero e idade.$^{10}$ Isso posto, foi realizado um recorte centrado em programas com características sensacionalistas e traços de violência em virtude de um questionamento geral, presente na sociedade, explicitado na criação da ONGs que debatem a programação da TV aberta e em discussões levadas a efeito em congressos e seminários que refletem sobre a sociedade atual. 


\section{Delineando a presença da violência na televisão}

$\mathrm{O}$ isolamento característico dos indivíduos que vivem nos grandes centros nos aponta para Arendt quando diz que: "a principal característica do homem de massa não é a brutalidade, nem a rudeza, mas seu isolamento e sua falta de relações sociais normais". ${ }^{11} \mathrm{Na}$ sociedade de massa, os meios de comunicação são a principal fonte de significação da realidade, trabalhando em função das ideologias, que "explicam os fatos (...) com uma onipotência que a tudo atinge", ${ }^{12}$ porém, sofrendo mediações diversas: comunicacionais, sociais, econômicas, psicológicas, políticas. Os significados seriam construídos a partir da Cultura em que se está 'inserido', esta estabelecida, em parte, por uma Ideologia que reflete as relações assimétricas de poder, entendendo Ideologia sentido a serviço do poder, poder este que hoje passa pela mídia, junto com o Estado, o sistema educacional e a família, instituições que utilizam formas simbólicas como meio de estabelecimento de sua representatividade, ideológicas nos contextos sócio-históricos específicos em que são existem e persistem. Na avaliação do fenômeno da recepção dos conteúdos da mídia e sua relação com o estado geral de insegurança que domina a sociedade, falamos de uma cultura constituída por teias, ${ }^{13}$ que representa, no sistema ideológico, um conjunto de mecanismos de controle para governar o comportamento, considerando que o homem é um animal amarrado a teias de significados que ele mesmo teceu.

\section{"violência na televisão} normalmente não é relacionada a programas jornalísticos, sejam eles de caráter sensacionalista

\section{ou não"}

Analisado no contexto urbano de grandes cidades, o consumo dos meios de comunicação de massa, especificamente jornais, revistas, rádio e televisão, é caracterizado pela rapidez e necessidade de informação sobre o ambiente social, econômico e político, nessa ordem. Dos meios impressos, o jornal dá uma visão geral dos acontecimentos e só se busca a revista quando há necessidade de 'detalhamento' e aprofundamento das informações. Os meios eletrônicos, rádio e TV, fazem parte do cotidiano. Respeitados os limites de acesso temporal, físico e financeiro, a relação com todos os meios é constante, contínua, rotineira, mas superficial. À medida que este acesso é ampliado, atingindo todos os estratos econômicos, culturais e sociais, a comunicação de massa torna-se "fonte primária de definições e imagens da realidade social e a expressão mais onipresente da identidade compartilhada, assim como o maior foco de interesse de lazer, que fornece meio ambiente cultural para a maioria das pessoas". ${ }^{14} \mathrm{O}$ rádio, opção para os horários em que não é possível ver a TV e a TV, centro do relacionamento receptormeios, principal fonte de informação, paliativo para diversão e lazer.

No caso específico da representação da violência, ainda que estatisticamente a era atual seja menos violenta do que o passado, a atuação dos meios de comunicação de massa torna a sociedade mais vulnerável às representações dos acontecimentos como conseqüência da valorização das formas simbólicas. Fruto da interação social, a violência é representada por meio de simplificações das complexidades de uma sociedade individualista apresentando, paradoxalmente, conteúdos que enfatizam situações relacionais ${ }^{15}$ "disseminando uma cultura centralizada em dois atores estereotipados: o verdugo e a vítima". ${ }^{16}$

Diante de um meio ambiente caracterizado pela violência, perguntamos: vivemos uma cultura da violência? Ou servimos a uma ideologia que alimenta esta cultura? Os programas populares reproduzem estruturas dos contos populares. As histórias partem de um problema "que rompe a ordem e o equilíbrio" originando "o herói e o vilão, o mediador e os vários ajudantes e intermediários"; o primeiro, que sai em defesa dos valores prioritários da cultura, passando por testes e provações; chegando ao triunfo; a recompensa e a celebração final, enfim o restabelecimento da solidariedade e da ordem sociocultural. ${ }^{17}$ De acordo Martín-Barbero, as chaves para explicar a caracterização dos conteúdos dos meios de comunicação de massa pelos dramas cotidianos, violência e sensacionalismo estariam na cultura popular, na estrutura da literatura de cordel e colportage, ${ }^{18}$ lembrando ainda que, nos Estados Unidos, a imprensa escrita só se populariza quando passa a divulgar "histórias de interesse humano e até descrições sensacionalistas de acontecimentos chocantes". ${ }^{19}$

Estas características ficam claras quando os resultados do estudo sobre a programação televisiva nos aponta que na televisão o sexo e a exploração da aberração são considerados temas mais violentos do que o ato criminoso em si. Em muitos casos a composição Texto + Imagem é violenta, com ênfase na utilização das palavras, que torna a situação violenta para $53,2 \%$ dos respondentes. Na fala do receptor sobre a composição Imagem+Palavras fica claro que as palavras dão sentido às imagens, e, talvez por isso as pessoas não considerem programas como Cidade Alerta ${ }^{20}$ e Brasil Urgente ${ }^{21}$ violentos, pois pouco ou quase nada comentam sobre as imagens mostradas. 
... mais violento em um programa?Eu acho que é o conjunto imagem, palavras. Não dá para você separar o que é mais. Mostrar por exemplo o pai e mãe que a filha matou ... mostram de longe, mas falam e as crianças entendem o que falam. Pode ser que não se veja o corpo nitidamente, mas estava ali. Se você pegar uma propaganda contra a fome, você vê imagens violentas, violência contra a integridade da pessoa, a pessoa passando fome, mas o texto não é uma mensagem de violência. $\mathrm{O}$ impacto que você sente daquela imagem não é uma mensagem de violência ... porque às vezes a pessoa pode estar usando uma palavras violenta e se você juntar com a imagem vai dar outro sentido. (...) $\mathrm{O}$ menino matou, decapitou a avó. Você pode falar isso sem mostrar o moleque, mostrar como era a avó, onde foi, o sangue da avó no meio da sala.

Indagadas sobre o que seria a violência na televisão, as pessoas consideram que a falta de respeito $(29 \%)$, as brigas em programas de auditório (23\%) são situações mais violentas. Homens e mulheres divergem quanto à importância da falta de respeito e do vocabulário utilizado, a primeira situação considerada mais violenta pelas mulheres, $35,4 \%$ contra $21,3 \%$ dos homens, e a segunda pelos homens, $4,9 \%$ contra $2,7 \%$ das mulheres. (tabela 1 )

\section{"na televisão, violência é maltratarem as pessoas no contexto do programa, ridicularizar 0 cidadão comum, explorar as mazelas do cotidiano"}

Violência na televisão normalmente não é relacionada a programas jornalísticos, sejam eles de caráter sensacionalista ou não. Violento é a dramatização exagerada, não reconhecida no conteúdo jornalístico, visto que a narração dos fatos, mortes, ataques, acidentes e desastres noticiados é considerada prestação de serviço. A interpretação destes conteúdos, na forma como são divulgados, é de alerta para a população, orientação sobre os perigos da cidade, o que promove o cenário de uma sociedade fora de controle, de uma cultura de violência ao contrário de uma cultura solidária, pois "o outro é sempre visto como um potencial inimigo de quem se deve, sobretudo, desconfiar". ${ }^{22}$

A interpretação da violência na televisão está relacionada com o gênero de programa. Solicitadas a nomear um programa violento, as pessoas não demonstram ter uma opinião claramente identificável sobre o assunto, resultando uma porcentagem de 21,5\% de citações diversas (tabela 2). As menções específicas se distribuem entre Linha Direta, da Rede Globo, Cidade Alerta e Programa do Ratinho, da Rede Record. A variedade de respostas nos leva a crer que, embora as pessoas tenham uma opinião determinada sobre o que seja violento, indicado na tabela 1 , nenhum programa reúne características suficientes para ser totalmente considerado violento, a violência tem aspectos diferenciados conforme o momento social. Em uma sociedade competitiva, se manifesta no cotidiano e é produto de mediações.

Agressivo ao telespectador é a exibição do corpo no programa do Gugu, "explorar situações com deficientes físicos" $(35,47 \%)$, "cenas que mostram sangue" $(28,2 \%)$, "explorar tiroteio entre polícia e bandido" (23,74\%). Esta percepção é de certa forma prevista tendo em vista um contexto social e cultural em que, senso comum, sangue é associado a desastre e morte. Para as pessoas economicamente menos favorecidas, incêndios e enchentes são fatos violentos, o que se justifica talvez pelas implicações de tais acontecimentos em favelas, seu local de moradia.

Eles mostram gente presa nas ferragens. Os bombeiros 'pelejando' para tirar, corpos estirados pelo chão. Mortos. Eu não me acostumo 'com' isso. E quando passa enchente então. (...) Eu também não gosto de incêndio. Incêndio, enchente, acidente de trânsito. O Datena não deixa mostrar sangue, nada. Não deixa mostrar a pessoa esmagada. Ele só conta o que aconteceu. E esclarece bem a gente.

As "cenas que mostram sangue" podem não ser consideradas tão agressivas, mas fazem $31,31 \%$ das pessoas entrevistadas "mudarem de canal", assim como "brigas de auditório", citadas por $27,9 \%$. A partir do que faz as pessoas mudarem de canal (tabela 3), compreendemos que as pessoas selecionam os conteúdos que lhes parecem mais interessantes ou que reforçam seus pontos de vista, suas opiniões e suas experiências. ${ }^{23}$

Violência na televisão passa então a ser a agressão vocabular, a exibição de cenas "fictícias" que mostram "quebra de regras", regras da televisão, originalmente entendida como meio de entretenimento. Quando a ficção ou o programa de auditório mostra o caos, imagens "feias", então é violência.

Violento? A Turma do Gueto. Eu só vi propaganda. Aquilo é horrível! É só soco, tiro, é favela, é tráfico, é arma! No Interligado são aquelas imagens de gente comendo bicho. No Ratinho, agressão entre homem e mulher, soco, murro, chute. 


\begin{tabular}{|c|c|c|c|}
\hline & TOTAL & HOMENS & MULthERES \\
\hline Falta de respeito & $20,1 \%$ & 21,334 & $35,4 \%$ \\
\hline Brigas em programos de auditório & $2,9 \%$ & $19,13 \%$ & $26,0 \%$ \\
\hline Cenos que mostram morte & $12,1 \%$ & $13,13 \%$ & $11,2 \%$ \\
\hline Mostrar a realidade & $10,3 \%$ & 9,336 & $11,2 \%$ \\
\hline Guerro por auditincio & $5,7 \%$ & 7,136 & $4,5 \%$ \\
\hline Mostrar sangue & $5,2 \%$ & 4,936 & $5,4 \%$ \\
\hline Cenos que envolvem sero & $4,7 \%$ & 4,436 & $4,9 \%$ \\
\hline Manipulaçōo de sìtuaçōes & $4,4 \%$ & $5,5 \%$ & $3,6 \%$ \\
\hline Armos & $4,2 \%$ & $3,33 \%$ & $4,9 \%$ \\
\hline Vocobulário & $3,7 \%$ & $4,93 \%$ & $2,7 \%$ \\
\hline Situoçōo oo vivo & $2,2 \%$ & 1,636 & $2,7 \%$ \\
\hline Nōo sabe & $2,0 \%$ & 3,896 & $0,4 \%$ \\
\hline Situaçôts que explorom crianços & $1,2 \%$ & $1,13 \%$ & $1,3 \%$ \\
\hline Outros & $17,2 \%$ & 2334 & $12,6 \%$ \\
\hline
\end{tabular}

\begin{tabular}{lc}
\hline Linha Direto & $27,5 \%$ \\
\hline Cidode Alerto & $25,8 \%$ \\
\hline Outros & $21,59 \%$ \\
\hline Programa do Ratinho & $14,4 \%$ \\
\hline Em branco & $6,0 \%$ \\
\hline Datena (Brosil Urgente) & $5,5 \%$ \\
\hline
\end{tabular}

Fala muito palavrão. É pancada do começo ao fim do filme. Eu acho que explodir um carro não é uma violência, mas ... matar, sim.

\section{Mas, afinal, o que é violento na TV?}

Na classificação geral de opiniões sobre a programação de TV, as pessoas mostram-se indecisas sobre o grau de violência presente nos desenhos animados. Pica-pau é considerado violento por 50,4\% dos respondentes, enquanto $10,8 \%$ dizem não saber ao certo. $O$ gênero 'desenhos animados' aparece como resposta espontânea, porém, dada a oportunidade de refletirem sobre o assunto, o desenho animado não é considerado violento, em especial os chamados 'clássicos', Pica-pau, Tom e Jerry. Se existe violência nos desenhos animados, está concentrada nos desenhos que apresentam personagens em formato humano, lutando pelo poder, como Pokémon que incita a violência porque seus personagens são pessoas. O Pica-pau só luta para se defender, o desenho fica violento a partir do momento que alguém o provoca, o que justificaria um eventual ato violento. Tom e Jerry também não é violento, o gato e o rato brigam mas são amigos.

\section{TABELA 1}

0 que é violência na TV?

(pergunta de resposta múltipla)

TABELA 2

Um programa violento.

TABELA 3

0 que considera agressivo e o que o faz mudar de canal. (pergunta de resposta múltipla)

\begin{tabular}{|c|c|c|}
\hline & AGRESSINO & $\begin{array}{c}\text { MUDA DE } \\
\text { CAMAL }\end{array}$ \\
\hline Explorar situoçóes com deficientes fisicos & $35,5 \%$ & $34,95 \%$ \\
\hline Cenos que mostrom sangue & $28,23,6$ & $31,31 \%$ \\
\hline Explorar tiroteios entre policio e bandidos & $23,7 \%$ & $27,67 \%$ \\
\hline Brigas em programas de auditório & $20,1 \%$ & $27,91 \%$ \\
\hline Uso de polaurōes & $19,5 \%$ & $19,66 \%$ \\
\hline Explorar o lado pejorativo & 19,336 & - \\
\hline Cenos que envolvem sesto & $12,6 \%$ & $13,83 \%$ \\
\hline Programas de pegadinhes & $10,9 \%$ & $18,20 \%$ \\
\hline Filmes com explosóes & $3,1 \%$ & $5,58 \%$ \\
\hline Assiste a fudo & - & $20,87 \%$ \\
\hline
\end{tabular}

Pica-pau, Tom e Jerry e Ligeirinho são defendidos em nome de uma lição de moral e ética, ao passo que Pokémon e Dragon Ball não apresentam nenhum contexto que ajude na construção do caráter das crianças. Essa é a opinião geral, com algumas variações conforme existissem crianças pequenas na residência do respondente. Para as mães, desenhos podem ser mal interpretados pelas crianças menores de 5 anos, pois nessa faixa etária, a criança não se concentra tempo suficiente em um mesmo programa para ver começo, meio e fim, o que dificulta a compreensão de uma provável mensagem presente no desenho.

Quando você assiste ao Pokémon você vê, ele retrata pessoas normais. Eles retratam um garoto e a criança acaba se identificando. Antigamente a violência que surgia era mais por defesa. Na maioria dos desenhos ... a pessoa tem que atacar ... o ataque virou a coisa mais importante e não a defesa. No Dragon Ball, eles fazem competição para saber quem é o mais poderoso, é uma briga para saber quem tem mais poder. Aí é que está a diferença, entre ficar quieto e se defender. 


\begin{tabular}{|c|c|c|c|c|c|c|}
\hline & $\begin{array}{ll} & \text { E } \\
\text { EXAGERA } & 0 \\
\end{array}$ & $\begin{array}{l}\text { EXPLORA OS } \\
\text { DRAMLAS DO } \\
\text { COTIDIAMO }\end{array}$ & $\begin{array}{l}\text { DESRESPEITA } \\
\text { AS PESSOAS }\end{array}$ & $\begin{array}{l}\text { EXPLORA A } \\
\text { DESGRACA } \\
\text { ALHEIA }\end{array}$ & $\begin{array}{l}\text { AUDDA AS } \\
\text { PESSOAS }\end{array}$ & \multirow{11}{*}{$\begin{array}{l}\text { TABELA } 4 \\
\text { Opinião sobre conteúdos } \\
\text { especííicos. } \\
\text { TABELA } 5 \\
\text { Outros programas que... }\end{array}$} \\
\hline Programa do Ratinho & $28,65 \%$ & 13,3046 & $34,20 \%$ & $8,4 \%$ & $8,17 \%$ & \\
\hline Gidade Alerto & $14,89 \%$ & $32,99 \% \%$ & - & $16,0 \%$ & - & \\
\hline Conal Aberto (Jocio Kleber) & $12,03 \%$ & - & $13,95 \%$ & $6,2 \%$ & - & \\
\hline Hora da Verdade (Márcio) & $10,39 \%$ & $16,11 \%$ & $11,35 \%$ & $13,9 \%$ & $6,74 \%$ & \\
\hline Brasil Urgente (Dateno) & $5,34 \%$ & 7,9334 & - & $4,59 \%$ & - & \\
\hline Nōo há & - & $5,373 \%$ & $11,00 \%$ & $6,7 \%$ & $32,97 \%$ & \\
\hline SPTV & - & - & - & - & $11,72 \%$ & \\
\hline Domingo Legal (Gugu) & $\longrightarrow$ & - & - & $6,5 \%$ & - & \\
\hline Linha Direto & - & - & - & $4,8 \%$ & - & \\
\hline Outras & $28,65 \%$ & $24,35 \%$ & $31,13 \%$ & $7,7 \%$ & $41,42 \%$ & \\
\hline Exuorasm & $\begin{array}{l}\text { EXHORAM OS DRAMLS } \\
\text { DO COIIDIANO }\end{array}$ & & $\begin{array}{l}\text { ESERESPEITAM } \\
\text { AS PESSOAS }\end{array}$ & & $\begin{array}{l}\text { DELORAM A } \\
\text { SGRACA ALAEIA }\end{array}$ & AUDAM LS RESSOLS \\
\hline Te vi no TV & & & & & & Silvio Santos \\
\hline Sérgio Molandro & & Sérgio & Molandro & Sérgio M & lalandro & Globo Rural \\
\hline $\begin{array}{l}\text { Repórter Cidadáo } \\
\text { Policiois }\end{array}$ & Repónter Cidadáo & & & Repórter & Cidadáo & $\begin{array}{l}\text { Globo Reporter } \\
\text { Domingo da Gente } \\
\text { (Netinho) }\end{array}$ \\
\hline Programos de auditório & Nowelas & & & Program & tes de ouditório & $\begin{array}{l}\text { Ana Maria Brago } \\
\text { Pequenes Empresos, } \\
\text { Grandes Negótios }\end{array}$ \\
\hline Linha Direta & Linha Direto & Linha & Direto & & & Linho Direto \\
\hline Domingo Legal (Gugu) & $\begin{array}{l}\text { Domingo Legal (Gugu) } \\
\text { Telejornais } \\
\text { Domingo do Gente } \\
\text { (Foustóo) }\end{array}$ & $\begin{array}{l}\text { Cidade } \\
\text { Pegadi }\end{array}$ & $\begin{array}{l}\text { e Alerto } \\
\text { linhos }\end{array}$ & Domingo & Legol (Gugu) & Telejornais \\
\hline
\end{tabular}

\section{Programas não são violentos somente porque mostram mortes}

Ser violento na televisão é mais do que mostrar a morte, cenas sangrentas. A violência não está na programação de televisão, mas sim na sociedade. $\mathrm{O}$ jornalismo apenas retrata o que acontece na cidade e a ficção dramatiza. Na televisão, violência é maltratarem as pessoas no contexto do programa, ridicularizar o cidadão comum, explorar as mazelas do cotidiano. No detalhamento dos aspectos negativos da programação televisiva, o Programa do Ratinho é o mais lembrado. Em seguida, os entrevistados citam gramas que exageram na exploração de situações que possam gerar audiência pelo sensacionalismo e que desrespeitam as pessoas, ainda que a Hora da Verdade seja também considerado um programa "que ajuda as pessoas". Cidade Alerta é também um pro- grama que exagera, explora a desgraça alheia e, em especial, os dramas do cotidiano (tabela 4). Como "Outros" nesta classificação temos a distribuição mostrada na tabela 5.

Os programas considerados "que exageram" são aqueles que reúnem grande parte das características consideradas violentas, como violência física, sangue, exploração da desgraça, morte. Nos comentários, notamos que muitas vezes o que incomoda é a representação na televisão daquilo que as pessoas, principalmente quem trabalha na rua, vêem no seu cotidiano. Porém, cabe notar aqui que este foco de observação dos fatos do dia-a-dia pode ser produto de uma influência da repetição dos mesmos na televisão. Essa resposta seria fruto do que Arendt chama de principal característica do homem de massa "seu isolamento e sua falta de relações sociais nor- 
mais". O isolamento característico dos indivíduos que vivem nos grandes centros urbanos ofereceria espaço para uma exposição seletiva a acontecimentos agressivos no seu cotidiano, respondendo a uma ideologia da violência.

Nos programas o Ratinho, o Leite, João Kleber, Sérgio Malandro, tudo é exagerado. Eles abusam. Mulher pelada, naquelas pegadinhas, pancadaria para tudo quanto é lado. Não tem escrúpulo nenhum. Virou banal. O Ratinho faz pouco caso dos outros! Quando vêm aqueles coitados, falam aqueles absurdos, e ele incentiva!

\section{Conclusão}

No estudo apresentado procuramos compreender os efeitos de sentido tendo em vista que é no discurso que ocorre a relação entre o pensamento, a linguagem e o mundo e que a Ideologia é um mecanismo estruturante dos processos de significação, das maneiras como o sentido é mobilizado para manutenção da relação de dominação. ${ }^{24}$ Isso é possível porque dominação depende de um composto de elementos estruturais que abarcam aspectos materiais e temporais. Vivemos num contexto mais do que ideológico, em que o 'real' é orientado por interesses, que se compactuam em alianças com base na dinâmica de escolhas culturais. A análise dos significados dados aos conteúdos dos programas de TV, os comportamentos notados: a aversão (nada presta), a des-sensibilização (o mundo é assim mesmo), até a apatia ou mesmo a elaboração (eu converso sobre os programas) nos mostra a superfície de uma leitura que reflete, acima de tudo, uma assimilação hegemônica da representação dos acontecimentos.

Esta assimilação hegemônica, entretanto, não reflete os pressupostos de uma abordagem "apocalíptica", que vê os receptores como um grupo à mercê de um sistema simbólico dominante, que alimenta a passividade e o conservadorismo, ${ }^{25}$ pelo contrário, cada um 'se vê na televisão' sob uma perspectiva: vítima ou algoz, reflexo ou fonte. A televisão funciona como uma oportunidade de sentir-se parte do contexto maior, concorrendo para a identificação popular na cultura hegemônica, permitida pelas indústrias culturais.

A pergunta-chave 'o que é realmente violento na televisão?' teve como resposta o desrespeito ao indivíduo, a exploração da desgraça. A audiência se dá pela falta de opção, e a curiosidade é um dos principais aspectos motivacionais de recepção de conteúdos criticados pelo sensacionalismo e exposição desnecessária de mazelas e situações desrespeitosas do ser humano. As pessoas não consideram os programas violentos porque nada é exposto com lógica. A carnavalização dos acontecimentos dificulta a reflexão. Quando o receptor diz que a televisão "não faz nada além do que retratar a realidade", ele está em consonância com um contexto ideológico que mostra uma sociedade violenta como nunca, sem que isso se confirme nas estatísticas históricas.

\section{"fora da televisão, a violência é um ato que gera danos; na televisão, ela é relativizada, a partir do simbólico"}

Os fatos são vistos isoladamente, não há contextualização ou reflexão. A TV torna-se uma grande catarse, um meio pelo qual as pessoas refletem seus medos e angústias em morar em uma cidade complexa. Vivemos uma cultura individualista que colabora para a manutenção de uma condição de dominação hegemônica. As pessoas não se sentem parte de um todo, responsáveis pelo mesmo, para o que colaboram os meios de comunicação de massa, em especial a televisão, na medida em propagam a diversidade, a liberdade de escolha, ainda que essa não seja a característica da programação. Mas, mesmo que as estratégias comunicacionais não permitam leituras que extrapolem as situações sociais estabelecidas por uma dinâmica capitalista, consumista, em que "muitos nasceram para ter pouco e poucos para terem muito", percebemos que cada um 'reflete' sobre esses conteúdos e seu significado dentro da sua realidade.

Fora da televisão, a violência é um ato que gera danos; na televisão, ela é relativizada, a partir do simbólico: uma cena pode ou não ser violenta dependendo do contexto. A reação da população à divulgação dos ataques do crime organizado, com flashes dos vários pontos da cidade, com informações fragmentadas, reforça os resultados do estudo realizado: o valor dos meios, em especial da TV, é simbólico, um simbolismo que se reflete na compreensão dos meios como fonte de informação. Nos programas reconhecidamente editados, produzidos com fins de entretenimento violência é a 'falta de respeito ao ser humano', já nos programas jornalísticos, mesmo os de abordagem duvidosa dos fatos, o que é mostrado serve à orientação. É quando a população se aterroriza ao tomar conhecimento dos ataques e 'encerra o expediente' em meio a uma tarde de dia de trabalho, procurando a segurança de seus lares. Do outro lado, as facções criminosas, como os grupos terroristas, forçam a entrada na dinâmica dos meios de comunicação, regulada por interesses econômicos, provocando ocorrências que sejam de interesse midiático.

O indivíduo não mais está restrito aos círculos familiares e comunitários, mas é parte de um ambiente sociocultural-econômico-político globalizado, mediado, vivendo um cotidiano que reflete e refrata 
uma complexidade originária da diversidade, mas que só é lembrado quando se torna sua vítima. Os atos criminosos são considerados violentos, e dignos de divulgação na mídia, quando provocaram a destruição de bens, ocorrendo então a intimidação, movimentando a população, que, só então, modifica o seu cotidiano. maAmecos

\section{NOTAS}

1. Organizado pela FELAFACS, sediado no Memorial da América Latina, em São Paulo, em outubro de 2000 .

2. WIRTH, Louis. O urbanismo como modo de vida. In: VELHO, Otávio Guilherme (org.). O fenômeno urbano. Rio de Janeiro: Zahar, 1967.

3. CARCATERRA, Lorenzo. Sleepers: vivendo um pesadelo. Trad. Affonso de Mello Franco. Rio de Janeiro: Record, 1996, pp. 131-134.

4. CRIME S.A. Revista Super Interessante. Junho de 2006, edição 227, pp. 76-81.

5. CRIME S.A. Revista Super Interessante. Junho de 2006, edição 227, p. 77.

6. Jaqueline Muniz, antropóloga, para Revista Super Interessante. Junho de 2006, edição 227, p. 78.

7. MONTES, Maria Lúcia Aparecida. Violência, cultura popular e organizações. In: VELHO, Otávio Guilherme (org.). O fenômeno urbano. Rio de Janeiro: Zahar, 1967, pp. 220-223.

8. MICHAUD, Yves. A Violência. São Paulo: Ática, 1989, p. 66.

9. MONTES. Violência, cultura popular e organizações ... op. cit., p. 225.

10. A pesquisa de campo foi realizada junto à população do ABC Paulista (SP), no segundo semestre de 2002.

11. apud SOUKI, Nadia. Hannah Arendt e a banalidade do mal. Belo Horizonte: UFMG, 1998, p. 68.

12. SOUKI. Hannah Arendt .... op. cit 1998, p. 67.

13. GEERTZ, Clifford. A interpretação das culturas. Rio de Janeiro: LTC, 1989, p. 15.

14. McQUAIL, Denis. McQuail's mass communication theory. 4th ed., London: SAGE, 2000.
15. ROCHA, Everardo. A sociedade do sonho. Rio de Janeiro: Mauad, 1995, passin.

16. TRIVINHO, Eugênio. Violência, cultura mediática, medo - ensaio de crítica sociopsicanalítica da sociedade tecnológica e da comunicação. In: TRIVINHO, Eugênio, LOPES, Dirceu Fernandes (orgs.). Sociedade mediática - significação, mediações e exclusão. Santos (SP): Universitária Leopoldianum, 2000, p. 34 .

17. WHITE, Robert (editor). Televisão como Mito e Ritual. Revista Comunicação \& Educação, São Paulo: CCA-ECA-USP/Moderna, ano I, no. 1, set./dez., 1994, p. 68.

18. MARTÍN-BARBERO, Jesús. Dos meios às mediações - comunicação, cultura e hegemonia. Rio de Janeiro: UFRJ, 1997, pp. 148-150.

19. DeFLEUR, Melvin L. e BALL-ROKEACH, Sandra. Teorias da comunicação de massa. Rio de Janeiro: Jorge Zahar, 1993, p. 67.

20. Cidade Alerta da Rede Record, no ar desde 1995. No período da pesquisa, 2002-2003, apresentado de segunda a sábado, para todo o Brasil, no horário das $17 \mathrm{~h} 45$ às $19 \mathrm{~h} 35$.

21. Brasil Urgente, Rede Bandeirantes, desde 2001. Apresentado de segunda a sábado, para todo o Brasil, no horário das $18 \mathrm{~h}$ às $19 \mathrm{~h} 35$. No primeiro semestre de 2003, passa para o comando de José Luiz Datena, adotando o mesmo enfoque que Cidade Alerta.

22. RONDELLI, Elisabeth. Dez observações sobre mídia e violência. Revista Comunicação \& Educação, São Paulo: CCA-ECA-USP/Moderna, no. 7, set./dez., 1996, p. 35.

23. WRIGHT, Charles. Sociologia da audiência. In: Comunicação da Massa. Rio de Janeiro: Bloch Editores, 1973, p. 68.

24. ORLANDI, Eni P. Análise de discurso - Princípios e Procedimentos, 3a. ed.. São Paulo (Campinas): Pontes, 2001, p. 96.

25. TODA Y TERRERO, José Martinez de. O impacto moral e social dos meios de comunicação. Revista Comunicação \& Educação, São Paulo: CCAECA-USP/Moderna, no. 7, set./dez., 1996, p. 41. 